\title{
HOW DOES EMPATHY HELP US TO UNDERSTAND OTHERS?
}

WHAT DOES IT MEAN TO UNDERSTAND SOMEONE ELSE? SOME WOULD SAY IT REQUIRES KNOWLEDGE OF WHAT THAT PERSON IS GOING THROUGH. OTHERS WOULD SAY SHARED PERSONAL EXPERIENCE IS NEEDED. ONE REQUIREMENT FOR UNDERSTANDING IS EMPATHY, THE SKILL OF SHARING ANOTHER PERSON'S PERSPECTIVE. AT THE UNIVERSITY OF LIVERPOOL IN THE UK, PROFESSOR THOMAS SCHRAMME IS INVESTIGATING THIS CONNECTION BETWEEN EMPATHY AND INTERPERSONAL UNDERSTANDING. WITH A TEAM OF RESEARCHERS, HE IS DEVELOPING A PHILOSOPHICAL THEORY TO EXPLAIN THE CONCEPTS BEHIND INTERPERSONAL UNDERSTANDING, AN ABILITY THAT IS INCREASINGLY IMPORTANT IN TODAY'S POLITICALLY AND CULTURALLY DIVIDED WORLD

\section{TALK LIKE A PHILOSOPHER}

EMPATHY - the ability to share the perspectives and feelings of another being

\section{INTERPERSONAL}

UNDERSTANDING - to gain appreciative knowledge of thoughts and feelings of others

SYMPATHY - the feeling of pity or sorrow for someone else

PHILOSOPHY - the study of foundational questions regarding all aspects of human and natural being, including knowledge, the mind, ethics and existence

\section{DEVELOPMENTAL PSYCHOLOGY}

the scientific study of how human thought and behaviour change over a lifetime

EMOTION REGULATION - the ability to manage and respond to our emotions
Many of us find it hard to understand the decisions that other people make. We may be concerned that our actions are not understood by others, we get frustrated when our friends and family cannot see something from our point-of-view, and we struggle to comprehend how someone could commit an atrocious act like murder. But why is it so hard to understand each other, and what prevents us from putting ourselves in someone else's shoes?

Empathy is a skill that enables us to take the perspective of other beings and feel what they feel. Professor Thomas Schramme, a philosopher at the University of Liverpool, is using philosophical discussion and psychological findings to develop a theory relating empathy to interpersonal understanding. In a world that is becoming increasingly politically and culturally divided, this theory will aid future discussions by increasing our knowledge of how we understand each other.

\section{EMPATHY AND INTERPERSONAL} UNDERSTANDING

"Empathy is not itself a moral skill," says

Thomas, "but a mode of gaining understanding of another being." For example, some con artists are very good at 'getting into the heads of others', and so are good at empathy, but they are not caring or moral, rather they use their skill in empathy to cheat others. Empathy is also often confused with sympathy, which is the feeling of sadness or pity you may feel if someone else is sad, whereas empathy involves a broader understanding of others.

Like any other skill, to be used successfully, empathy needs to be practised and developed over time. When used correctly, empathy provides a way to access the minds of others, helping us to understand their thoughts and actions, and enabling us to interact with them.

Although empathy plays an important role in connecting with others, more seems to be needed for full understanding. To some people, 'understanding' means knowing why someone else is feeling a certain way, while for others, it requires a shared personal experience.

"For example, we struggle to empathise with people who commit hideous crimes," explains Thomas. "In consequence, we can fail to understand them, even though we might know their motives." Empathy and understanding, therefore, appear to be heavily linked, but 


\section{ABOUT PHILOSOPHY}

Philosophy is the study of knowledge, the mind, ethics and our very existence. For thousands of years, we have been asking ourselves, "Why are we here?' and 'How do we even know that we exist in the way we perceive ourselves in the world?' And today, philosophers are still trying to answer these questions.

Thomas specialises in moral and political philosophy, combined under the term 'practical philosophy' due to their concern with practices and actions. Humans behave in ways that have practical repercussions, for example someone's actions may harm others, and moral and political philosophy involves asking questions about how we should behave.

Thomas is also interested in the philosophy of medicine. "Pretty much all traditional areas of philosophy can be applied to medicine," he says. Ontology is the philosophical study of what exists and in what way. "This can be applied to the philosophical debate of whether mental disorders exist, or whether they are brain diseases," explains Thomas. Epistemology, the study of knowledge, can be used to investigate how medical conditions are diagnosed. "Are patients' illnesses diagnosed using certain rules and medical data?" asks Thomas. "Or do doctors use their intuition and experience to treat patients?"

\section{WHAT ARE THE JOYS AND CHALLENGES} OF BEING A PHILOSOPHER?

"I like the open nature of philosophy," says Thomas. "There is no topic that might not become the object of philosophical thinking." Thomas loves spending his working hours reading and thinking, allowing him to pursue his personal enjoyments as his job.

However, Thomas highlights this can also be a problem, as philosophy does not deliver products in a traditional way. "Philosophers don't invent new technology or identify lifesaving treatments," he says. This can lead some people to think that philosophy is a superfluous activity, nice if you have the time for it, but not a serious economical pursuit. Thomas thinks it's important to fight this distorted image. "The benefits of philosophy are vast and they concern human thinking by offering new perspectives," he says. "This does not have a monetary value but is invaluable nonetheless."

\section{WHAT IS THE FUTURE OF PHILOSOPHY?}

Despite the challenges facing modern philosophers, Thomas thinks the field is an exciting one to work in. "You never know what philosophical issues will arise. That's the beauty of it!" he says. "Suddenly, new ideas are introduced, and they change how we perceive the world."

Philosophers address human issues, such as racism and climate change, and so they are vital for understanding how we can all live with each other and our planet. And new technological developments have philosophical implications. Modern philosophers ask questions about artificial intelligence and debate the concept of the 'extended mind'. This view argues that our mental realm is not just inside our head but is extended to things in the world. With so much of our existence now dependent upon, and contained within, our phones, why are our phones not considered part of our mind? "Philosophy opens a completely new avenue of thinking and a new way of perceiving the world," says Thomas.

\section{EXPLORE A CAREER IN PHILOSOPHY}

The British Philosophical Association (www. bpa.ac.uk) contains resources for students (www.bpa.ac.uk/resources) and information for schools (www.bpa.ac.uk/philosophy-in-schools).

The Royal Institute of Philosophy (www. royalinstitutephilosophy.org) organises public lectures and you can watch philosophers talk about philosophical issues through their YouTube channel (www.youtube.com/userl RoylntPhilosophy).

For an accessible introduction to philosophy,

Thomas recommends Think, by Simon Blackburn, or any books by Julian Baggini.

Visit the University of Liverpool's Philosophy Department (www.liverpool.ac.uk/philosophyl outreach) to find out more about the subject.

Be aware that there is a lot of bad (pseudo-) philosophy information on the internet. Thomas says that you may need experience to distinguish between it and true philosophical work.

\section{PATHWAY FROM SCHOOL TO PHILOSOPHY}

- Reading and writing are essential skills for philosophers, and it is very useful if you enjoy them! Other necessary skills are the abilities to understand complicated debates, express your thoughts and form structured arguments.

. "Philosophers need the analytical skill of 'logic'," says Thomas. "They need to be able to unpick arguments by ascertaining whether a given conclusion logically follows the statements provided."

- Many universities offer philosophy degrees. To become an academic philosopher like Thomas requires a lot of luck, so he advises against being single-minded about such a career path. But a degree in philosophy will teach you many skills of reasoning and logic, which will open doors to a wide range of careers outside academia.

\section{THOMAS'S TOP TIPS}

OI Anyone can read philosophy and philosophise! Philosophy is a democratic pursuit.

02 See philosophy as an interpersonal activity. You don't think alone, you are constantly in a conversation with others, even if they are not always present in person. 
